\title{
A working methodology for deep energy retrofit of residential multi-property buildings
}

\author{
Cecilia Hugony $^{1}$, Maria Elena Hugony ${ }^{1}$, Francesco Causone ${ }^{2}$, Eugenio Morello ${ }^{3}$ \\ ${ }^{1}$ TEICOS UE S.r.l., Via Caviglia 3/a, 20139 Milano, Italy \\ ${ }^{2}$ Department of Energy, Politecnico di Milano. via Lambruschini 4, 20156 Milano, Italy \\ ${ }^{3}$ Department of Architecture and Urban Studies, Politecnico di Milano. via Bonardi 3, 20133 \\ Milano, Italy
}

\begin{abstract}
In many EU countries existing private condominium buildings represent an important energy problem to the attainment of the EU Energy objectives for 2020 and beyond. $41.7 \%$ of EU population lives in flats that are responsible for $68 \%$ of total energy use in buildings. Deep renovation of residential private buildings is therefore a paramount and critical issue for the achievement of the EU targets for building stocks. Where property is fragmented among many small owners, like in condominiums, the decision process is the major obstacle to the uptake of an adequate deep renovation.

In "Sharing Cities", a project granted by H2020 programme under Smart Cities and Communities initiatives, this barrier has been overcome through an innovative methodology based on citizens' participation and the collaboration between public and private sector. This paper describes the methodology and reports the last results to date for the lighthouse city of Milan.
\end{abstract}

Keywords: deep renovation, energy retrofit, citizen awareness, co-design

\section{Introduction}

Italy has 12 million of residential buildings; over $60 \%$ of them have been built more than 40 years ago, before the issue of any regulation on energy efficiency in buildings. According to Istat [1], $49 \%$ of the occupied dwellings is located in multi property (or condominium) buildings.

To foster energy renovation of the building stock in accordance with European directives, Italy adopted specific instruments:

- new legislations with mandatory energy efficiency targets for new buildings and, recently, new regulations for energy performance certifications and energy targets for existing and new buildings;

- VAT reduction to $10 \%$ for building retrofit;

- tax credit for $65 / 70 / 75 \%$ of the investment in energy efficiency renovation. 
Despite of this encouraging incentive framework, deep renovation (DR) represents just $0,4 \%$ of the total incentive allocated and most of the funding ( $68 \%$ in 2013 ) is spent for windows replacement only [2]. 34\% of the incentives are given to buildings three or more story high [3], and, according to ENEA, just 1,4\% of incentives have been requested for energy efficiency improvement of the opaque building envelope [4]. Moreover, an analysis of CRESME reports that in the last 15 years just $16 \%$ of the total surface of opaque building envelopes has been renovated or maintained [5].

This scenario shows that "the incentives (alone) do not contribute to a real reduction of energy needs in existing buildings" [6], but other actions are required. The principal barriers to Energy Efficiency (EE) in residential Multi Property Buildings (MPB) have been analyzed in the literature [7]; in particular, the major ones are:

- the lack of information to final clients about energy efficiency;

- the lack of specific financing instruments for energy efficiency in buildings (the capital investment is still not affordable for the majority of flat owners considering the payback time with current incentives);

- the difficult decision-making process in multi property buildings;

- the uncertainty of consistent economic savings after renovation.

Despite these difficulties, the ambitious goal of energy renovation of private residential buildings is implicitly confirmed in all planning tools both at a municipal and regional level. As an example, the action plan for sustainable energy of the municipality of Milan (SEAP [8]), and the Energy and Environmental Regional plan (PEAR [9]) establish goals for a reduction of emissions of global warming gases up to $55 \%$ in the period 2015-2020. Without the contribution of private buildings these and further objectives are not achievable.

This paper reports a successful attempt made in order to overcome the major barrier to energy renovation in residential multi property buildings, i.e. the decision-making process. To do so, we developed an innovative methodology within the EU granted project "Sharing Cities", that led, in about 3 years, to the deep energy retrofit of 5 private buildings in Milan, for a total area of $24000 \mathrm{~m}^{2}$. The following sessions describe the methodology and the major results to date.

\section{Nomenclature}

DR Deep Renovation

EE Energy Efficiency

MPB Multi Property Building

RES Renewable energy sources 


\section{$2 \quad$ Methodology}

\subsection{Overall strategy:}

In "Sharing Cities" [10] a specific task of the city of Milan was to realize deep energy renovations of MPB for about $21000 \mathrm{~m}^{2}$ of conditioned area. Among the several objectives of the project, this was considered one of the most challenging, since the flat owners had to pay by themselves for the majority of retrofit measures, with only $15 \%$ incentives on the total amount of the works, via EU funding.

Recognizing the pivotal role of people in this big challenge, an engagement and design strategy has therefore been developed, based on the direct participation of flat owners. It had the specific aim to increase people awareness on economic and environmental impacts of energy retrofit actions. The strategy was based on four pillars:

- virtuous competition among owner's communities;

- co-design process of the energy measures with the flat owners;

- environmental and energy monitoring of the retrofitted building and training on behavioral adaptation to post-retrofit scenario.

- development of a specific financial instrument to sustain the investment with a private bank.

In particular, the bank credit was accorded to the condominium (not to the single flat owner), with first rates due at the end of the renovations works (together with State's incentives), considering a cover factor of $100 \%$ of the costs and low interest rates $(3,5 \%)$.

The entire process has been applied to 20 condominium buildings in the South-Est area of Milan, with the ambitious goal of concluding real retrofit works on 5 of them.

\subsection{Engagement methodology:}

The methodology adopted for the engagement of flat owners in the 20 buildings, followed a precise sequence of steps:

- building nominations through a public call;

- feasibility study on respondents (52 buildings) and selection of pilot buildings ( 20 buildings);

- co-design process on selected owners' communities (20 buildings);

- technical design development;

- sharing and discussion of the energy audits with flat owners;

- financial instruments development and proposal;

- monitoring system design and deployment;

- post-retrofit guide sharing.

The Municipality of Milan issued a public call in order to select the most appropriate buildings. 52 buildings presented their nomination to the public call, and preliminary energy audits were undertaken to identify the buildings meeting the requirements of the 
project. Of the 52 candidates, 20 buildings resulted eligible from a technical point of view (see Fig. 1).

In order to overcome the barriers described in Session 1, a co-design process was set up by the principal project's partners: Politecnico di Milano, Poliedra, Legambiente, Comune di Milano and TEICOS, supported by FCC London, the work package leader. The co-design process accounted for three main meetings and an extra-meeting with the so called 'energy champions' of MPBs. The energy champions were groups of owners, identified in each building and present at the meetings, particularly pro-active and prone to collaborate with the project's partner to develop a proper energy renovation of their building.

The technical design process, developed by engineers and architects, had to go in parallel with the co-design process, in order to provide material to be shared and discussed with the owners' communities. The scheme reported in Figure 2 tries to represent the complexity of this "double-process" in terms of numbers of meetings and parallel co-design activities.

Specific communication tools (see Fig. 3) were developed in order to give people comprehensible information on the physical status of their buildings and on the opportunities of improvement. The reciprocal comprehension, made possible by the developed communication tools, allowed for an effective sharing of the information contained in the energy audit, that would have resulted, otherwise, as a technical and not comprehensible document for the majority of the people.

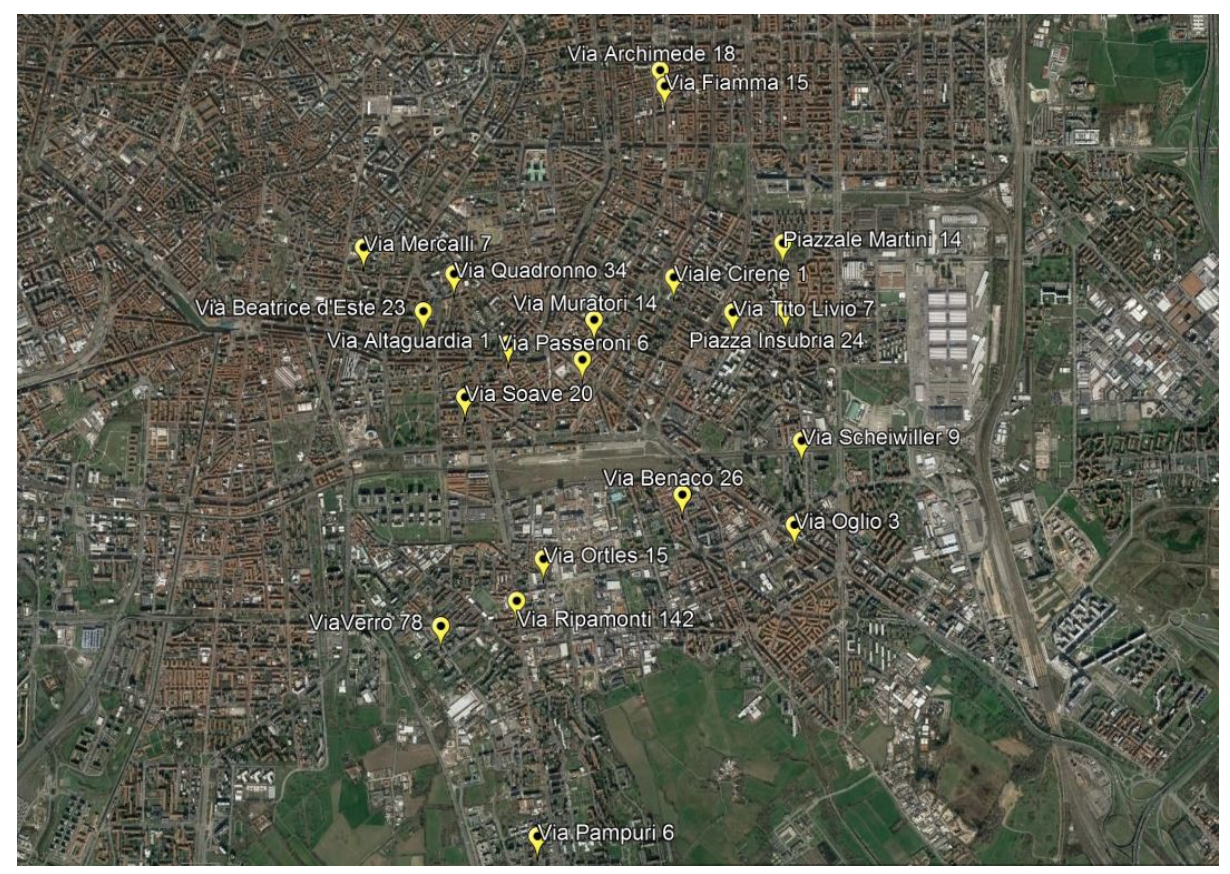

Fig. 1. 20 buildings that approved their participation to Sharing Cities 


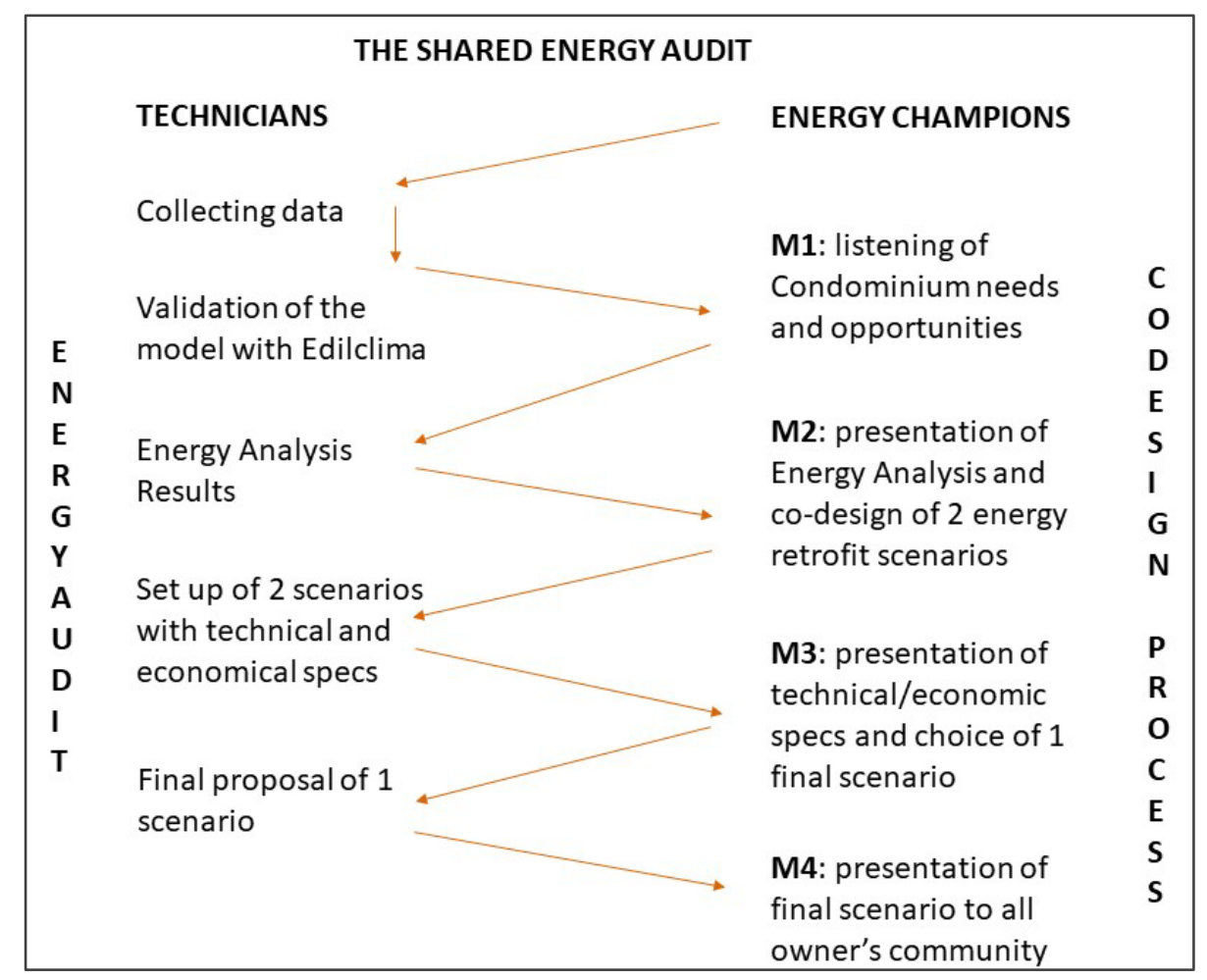

Fig. 2. The double process scheme of co-design and technical design

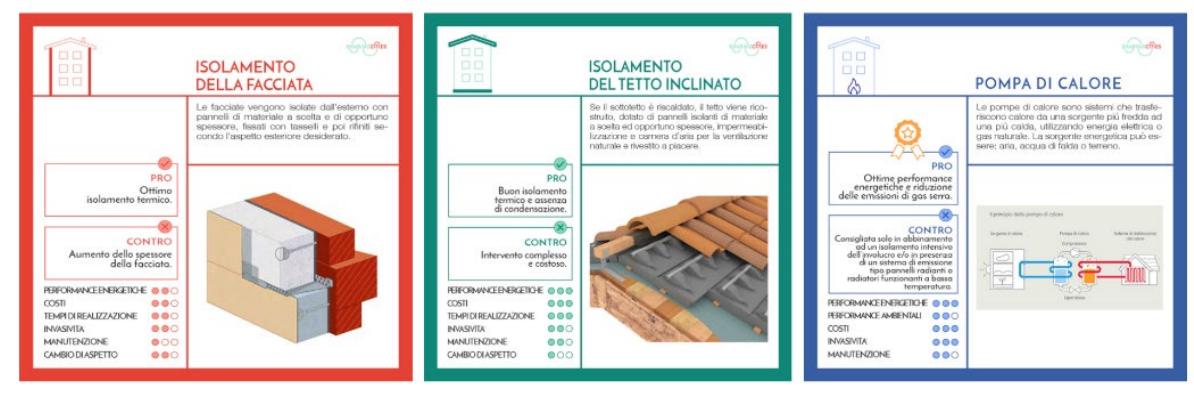

Fig. 3. Example of one of the communication tools provided to flat owners: 'EE measures postcards': measures possible for building envelope (red), roof (green), energy system (blue).

At the end of the co-design process, among 20 buildings, 5 approved the defined measures. During the process, a financial scheme was presented to the building owners, including all the incentives and integrated with a specifically developed bank loan proposal: with long term ( 7 years), low interest rates $(3,5 \%)$ and a cover factor of $100 \%$ of the costs.

A monitoring system was installed in 33 apartments of the 5 buildings, in order to assess the effect of the energy retrofit measures, and/or the change of behavior of flat 
owners after the implementation of the overall methodology in terms of raising awareness on the sustainability issues related to energy consumption in buildings. Besides energy consumption, the internal environmental quality is monitored with sensors of temperature, relative humidity, pressure, illuminance and TVOCs (Total Volatile Organic Compounds). Eventually, a user guide providing information on how operating and properly behave in a retrofitted building, in order to obtain energy saving together with high indoor comfort conditions, was developed together with Legambiente, an Italian ONG working on environmental and sustainability topics. This was shared with all flat owners participating to the co-design process, recognizing the pivotal role of the occupant on the actual building performance.

\section{$3 \quad$ Application and Results}

The goal of the co-design activity was to create a shared project of retrofit measures to be implemented in each building. During the workshop, the 20 buildings have been divided into three main working groups. Table 1 shows the summary of groups.

Table 1. Summary of group of condominiums.

\begin{tabular}{|l|l|l|}
\hline Group A & Group B & Group C \\
\hline Beatrice d'Este & Fiamma & Altaguardia \\
\hline Insubria & Mercalli & Archimede \\
\hline Martini & Oglio & Barzoni \\
\hline Passeroni & Ortles & Cirene \\
\hline Quadronno & Pampuri & Muratori \\
\hline Soave & Ripamonti & Scheiwiller \\
\hline & Verro & Benaco \\
\hline
\end{tabular}

9 workshops ( 3 meeting per group) with 160 residents (energy champions) from the selected 20 buildings were performed (see Fig. 4).
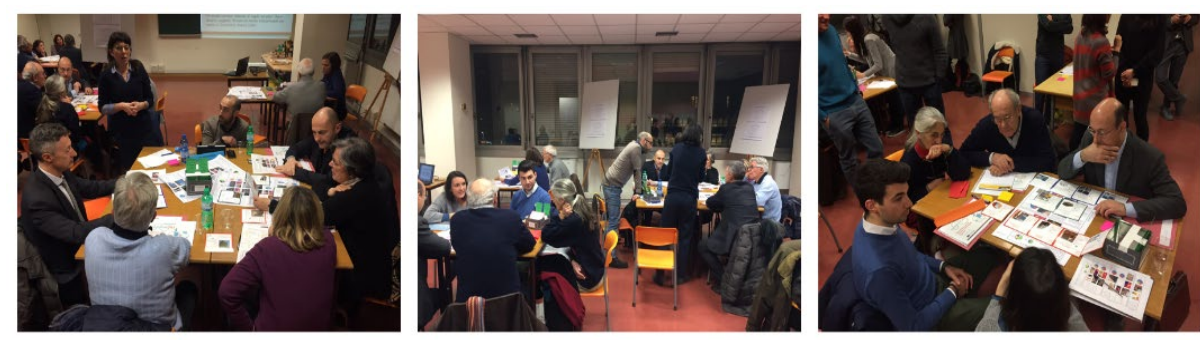

Fig. 4 Some picture from workshop \#2.

As a result of the co-design process and of the interaction between flat owners, architects and engineers, 40 different scenarios for buildings intervention have been developed, starting from the information gathered in the energy audit (each building 
firstly choose 2 scenarios: one more realistic and the other one more ambitious in terms of EE).

All the final mix of interventions chosen by the flat owners (see Tab. 2) included the thermal insulation of the opaque envelope, usually both vertical and horizontal, combined with PV system installation on the roof and/or new heating systems (gas heat pump or condensing boiler).

Table 2. EE measures chosen by building owner's during the co-design

\begin{tabular}{|c|c|c|c|c|c|c|c|c|c|c|c|}
\hline BUILDINGS & 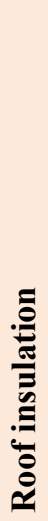 & a & 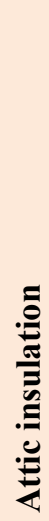 & 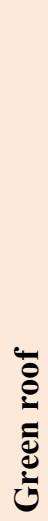 & 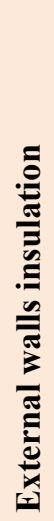 & 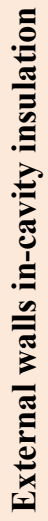 & 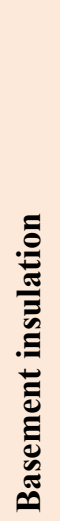 & 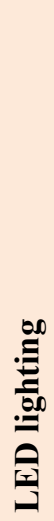 & 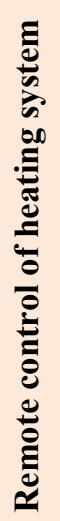 & 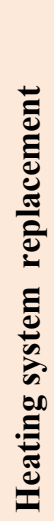 & $\frac{\dot{\Xi}}{\stackrel{0}{0}}$ \\
\hline Beatrice d'Este & $\mathrm{x}$ & $\mathrm{x}$ & & & $\mathrm{x}$ & $\mathrm{x}$ & $\mathrm{x}$ & $\mathrm{x}$ & $\mathrm{x}$ & $\mathrm{x}$ & \\
\hline Insubria & $\mathrm{x}$ & $\mathrm{x}$ & & & $\mathrm{x}$ & & $\mathrm{x}$ & & & & \\
\hline Martini & & $\mathrm{x}$ & & & $\mathrm{x}$ & & $\mathrm{x}$ & $\mathrm{x}$ & & & \\
\hline Passeroni & $\mathrm{x}$ & $\mathrm{x}$ & & & $\mathrm{x}$ & & $\mathrm{x}$ & & $\mathrm{x}$ & $\mathrm{x}$ & \\
\hline Quadronno & $\mathrm{x}$ & $\mathrm{x}$ & & & $\mathrm{x}$ & $\mathrm{x}$ & & & & & \\
\hline Soave & $\mathrm{x}$ & $\mathrm{x}$ & & & $\mathrm{x}$ & & $\mathrm{x}$ & $\mathrm{x}$ & $\mathrm{x}$ & & \\
\hline Fiamma & $\mathrm{x}$ & $\mathrm{x}$ & & & & $\mathrm{x}$ & $\mathrm{x}$ & $\mathrm{x}$ & & & \\
\hline Mercalli & $\mathrm{X}$ & $\mathrm{x}$ & & & $\mathrm{x}$ & & & & $\mathrm{x}$ & $\mathrm{x}$ & \\
\hline Oglio & & $\mathrm{x}$ & $\mathrm{x}$ & $\mathrm{x}$ & & $\mathrm{x}$ & $\mathrm{x}$ & & & & \\
\hline Ortles & $\mathrm{x}$ & $\mathrm{x}$ & & & $\mathrm{x}$ & & $\mathrm{x}$ & $\mathrm{x}$ & & & \\
\hline Pampuri & $\mathrm{x}$ & $\mathrm{x}$ & & & $\mathrm{x}$ & & & & $\mathrm{x}$ & $\mathrm{x}$ & \\
\hline Ripamonti & & & & & $\mathrm{x}$ & $\mathrm{x}$ & & $\mathrm{x}$ & & & \\
\hline Verro & $\mathrm{X}$ & $\mathrm{X}$ & & & $\mathrm{X}$ & & & $\mathrm{x}$ & $\mathrm{x}$ & & $\begin{array}{c}\text { Windows } \\
\text { replace- } \\
\text { ment }\end{array}$ \\
\hline Altaguardia & $\mathrm{x}$ & $\mathrm{x}$ & & & $\mathrm{x}$ & & $\mathrm{x}$ & $\mathrm{x}$ & & & \\
\hline Archimede & & $\mathrm{x}$ & $\mathrm{x}$ & & $\mathrm{x}$ & & $\mathrm{x}$ & & $\mathrm{x}$ & & \\
\hline Barzoni & & $\mathrm{x}$ & $\mathrm{x}$ & & $\mathrm{x}$ & $\mathrm{x}$ & $\mathrm{x}$ & $\mathrm{x}$ & $\mathrm{x}$ & & \\
\hline Cirene & & $\mathrm{x}$ & & & $\mathrm{x}$ & $\mathrm{x}$ & $\mathrm{x}$ & $\mathrm{x}$ & & & \\
\hline Muratori & & & & & $\mathrm{x}$ & & & & & & \\
\hline Scheiwiller & $\mathrm{X}$ & $\mathrm{X}$ & & & $\mathrm{x}$ & & $\mathrm{X}$ & $\mathrm{X}$ & & & $\begin{array}{c}\text { Solar thermal } \\
\text { panels }\end{array}$ \\
\hline Benaco & & $\mathrm{x}$ & $\mathrm{x}$ & & $\mathrm{x}$ & $\mathrm{x}$ & $\mathrm{x}$ & $\mathrm{x}$ & & & \\
\hline
\end{tabular}


After the co-design process, the retrofit works have been effectively approved by the condominium board for 5 buildings: Via Tito Livio 7, Via Fiamma 15/1, Via Verro 78 B/C, Via Passeroni 6, Via Benaco 26 (see Tab. 3). The pathway was short and followed the principle of 'first come, first served'. Indeed, the incentive provided by EU funding was covering only up to $21000 \mathrm{~m}^{2}$ of conditioned area; this has been a powerful driver to speed up the decision-making process.

All the site works have been concluded by the end of 2018, excluding Via Benaco, that is going to be concluded by August 2019. Since the entire process started in mid2016, with the Municipality's public call for nomination, we reached and exceeded the ambitious goal, and will complete the process with $24310 \mathrm{~m}^{2}$ of retrofitted surfaces in residential MPBs in about three years.

Table 3. Building Specifications

\begin{tabular}{|l|l|l|l|l|}
\hline NAME & $\begin{array}{l}\text { Year of } \\
\text { construc- } \\
\text { tion }\end{array}$ & $\begin{array}{l}\text { Number of } \\
\text { floors }\end{array}$ & $\begin{array}{l}\text { Number } \\
\text { of apart- } \\
\text { ments }\end{array}$ & $\begin{array}{l}\text { Total condi- } \\
\left.\text { tioned area } \mathbf{( m}^{\mathbf{2}}\right)\end{array}$ \\
\hline Via Passeroni 6 & 1963 & $4 / 6^{*}$ & 50 & 6.260 \\
\hline Via Tito Livio 7 & 1960 & 7 & 25 & 2.049 \\
\hline Via Verro 78 B/C & 1979 & 5 & 36 & 3.857 \\
\hline Via Fiamma 15/1 & 1967 & 7 & 15 & 3.314 \\
\hline Via Benaco 26 & 1960 & 6 & 141 & 8.830 \\
\hline
\end{tabular}

*Via Passeroni is a complex condominium composed by 3 buildings of 4 floors, 5 floors and 6 floors respectively

The retrofit works aimed at saving nearly $50 \%$ of energy (including all final energy uses), according to Sharing Cities' targets.

Considering that for the majority of the buildings the actual energy savings are expected in one-year time, after a whole heating season monitoring, some early observations can be done for space heating in the condominium of Via Verro $78 \mathrm{~B} / \mathrm{C}$, whose renovation works were concluded in May 2017. Table 4 reports the building energy use for space heating (delivered energy) before the retrofit and after the retrofit; it also includes the output of energy simulations, performed for energy certification, thus using a quasi-steady state approach according to standard UNI EN 13790 (in force at the time of the design) and the national standard series UNI TS 11300.

Table 4. Heating energy use in Via Verro $78 \mathrm{~B} / \mathrm{C}$

\begin{tabular}{|c|c|c|}
\hline Pre-retrofit (delivered) & Energy simulation & Post retrofit (delivered) \\
\hline $65,11 \mathrm{kWh} / \mathrm{m}^{2} \mathrm{y}$ & $37,08 \mathrm{kWh} / \mathrm{m}^{2} \mathrm{y}$ & $48,44 \mathrm{kWh} / \mathrm{m}^{2} \mathrm{y}$ \\
\hline
\end{tabular}

The actual energy use for the heating season $2018-19\left(15^{\text {th }}\right.$ October to $15^{\text {th }}$ April $)$ is higher than expected (i.e. higher than energy simulation results). The reason of this discrepancy depends on many factors: reference and actual weather, simulation input errors, and occupant behavior. The trend of the indoor temperature in a reference apartment (see Fig. 5) is useful to identify the large role played by occupant behavior in 
particular. Figure 5 shows that the indoor temperature in winter is always beyond the target comfort temperature of $20^{\circ} \mathrm{C}$, which means that the thermoregulation (i.e. thermostatic valves) was not properly used after the renovation works. If on the one hand this demonstrates that the real energy consumption is almost in line with the energy simulation output, excluding the effect of thermostatic valves, on the other hand it shows that the post-retrofit campaign to inform the users about a proper building operation was not (yet) properly effective.

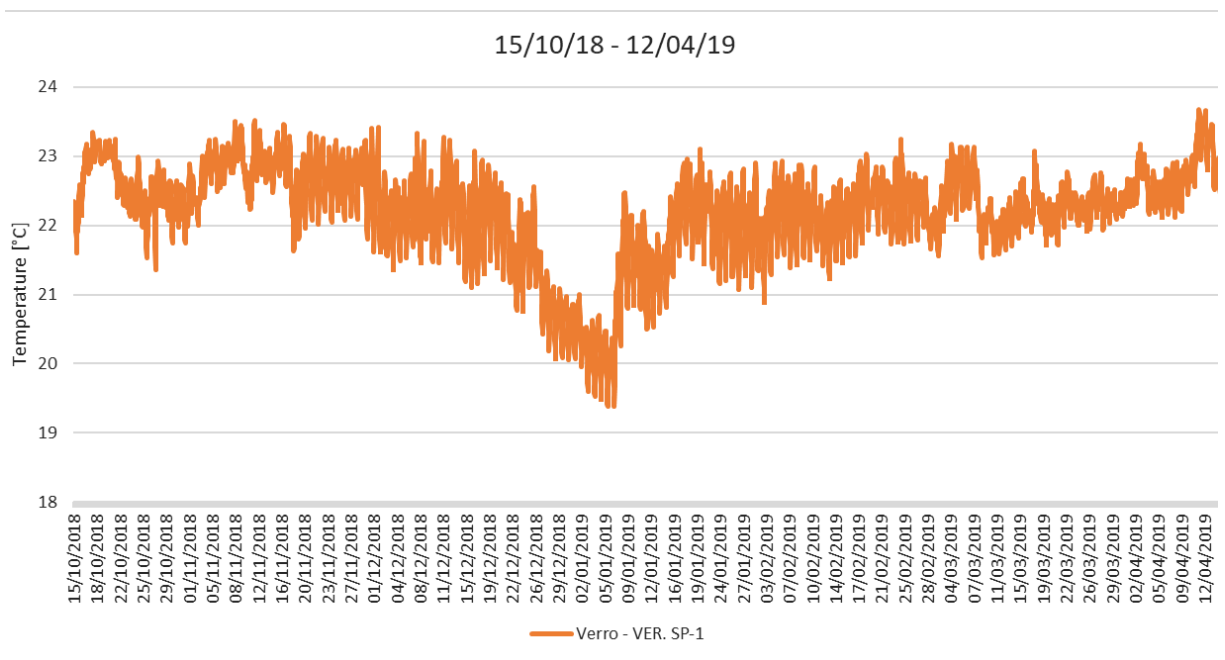

Fig. 5 Indoor air temperature in a flat of Via Verro (post- retrofit)

\section{Discussion and Conclusion}

The experience reported in this paper shows that non-technical barriers, which often represent the major limit to energy retrofit in residential multi property buildings, may be overcome through an approach based on co-design and people engagement. The success of the methodology depends on some key factors:

- Information sharing and co-design;

- timely and easy proposal of financial aspects;

- human centric approach.

Moreover, all the five renovated buildings presented in the paper, reported trigger points for renovation, that helped accelerating the process: asbestos removal on the roof (via Fiamma and Via Passeroni), water infiltration form the roof (Via Verro), façade decay (Via Benaco, Via Tito Livio, Via Passeroni, Via Verro). Identifying urgencies further than energy renovation, may help convincing owners to proceed with works, showing them the benefits deriving from a deep energy retrofit, with little investment costs on top of the basic urgent intervention. 
The very heart of the methodology is, nevertheless, the sharing of energy audits and the direct confrontation on technical solutions between flat owners and architects/engineers. The effective comprehension of the technical measures and their added value, is fundamental in order to achieve owners' commitment. People felt involved in the ambitious challenge of deep renovation also due to the institutional commitment and direct participation of the Municipality, of the University and of a NGO (Legambiente) in the activities. Having these partners on board helped creating trust in the process.

In order not to hinder the procedure, financial aspects should be presented only at the end of the technical process, once the owners agreed on the technical benefits of the retrofit measures and they are ready to properly weigh their economic value.

In general, the flat owners should become the pivotal point of the retrofit. The experimented methodology, showed us that four meetings are enough to help the designer or promoter understanding the peculiar building community, owners' expectations and initial ideas, paving the way to a more effective dialog and cooperation.

The only part of the methodology that, at the moment, did not show totally effective was the post-retrofit campaign to inform the users about a proper building operation. This informational and educational process should be better structured considering the wide variety of users and habits that might be encountered: retired people, students, working population, singles, families, locals, immigrants, etc.

In conclusion, the proposed methodology showed to be effective and could be further repeated, perhaps creating a more structured approach based on a larger and continuous commitment of the Municipality or other professional actors such as a 'process facilitator'.

\section{Aknowledgment}

The study was developed within the framework of the project SHAR-LLM, which has received funding from the European Union's Horizon 2020 research and innovation programme under grant agreement No 691895.

The design and co-design activities (including energy audit and simulations, retrofitting measures and financial budget and tools) have been promoted and led by TEICOS as part of the Sharing Cities project. Energy audits, simulations and design activities have been implemented by TEICOS. The co-design methodology was developed by the Department of Architecture and Urban Studies (Dastu) of the Politecnico di Milano with TEICOS and the contributions of Legambiente and Poliedra. The workshops and engagement activities have been organized carried out by TEICOS with Legambiente, Dastu, Poliedra and supported and hosted by the Municipality of Milan and the local Municipality 4. The monitoring system was designed and installed by Future Energy and TEICOS with the support of the Department of Energy of the Politecnico di Milano that also carried out the data analysis.

\section{References}

1. ISTAT Homepage, https://www.istat.it/it/files/2015/12/C18.pdf, last accessed 2016/05/15. 
2. Nocera, M.: Le detrazioni fiscali del 55-65\% per la riqualificazione energetica del patrimonio edilizio esistente nel 2013, pp. 8. ENEA, Roma (2015).

3. Nocera, M.: Le detrazioni fiscali del $55-65 \%$ per la riqualificazione energetica del patrimonio edilizio esistente nel 2013, pp. 21-22. ENEA, Roma (2015).

4. Nocera, M.: Le detrazioni fiscali del 55-65\% per la riqualificazione energetica del patrimonio edilizio esistente nel 2013, pp. 26. ENEA, Roma (2015).

5. D'Assandris, P.: Valutazione della convenienza e dell'impatto economico dell'isolamento termo acustico degli edifici. In: Riqualificare gli edifici, una necessità per il rilancio del paese. Le opportunità del risparmio energetico per l'economia ed il benessere dei cittadini. CONFERENCE 2014, pp. 35. FIVRA, Roma (2014).

6. Renovate Italy Homepage, https://renovateitaly.files.wordpress.com/2015/05/position-paper_completo_26ott15.pdf, last accessed 2015/10/31.

7. RSE: Edifici energeticamente efficienti: un'opportunità, pp. 91-95. ALKES, Milano (2015).

8. AMAT: Piano di Azione per l'Energia Sostenibile (PAES) del Comune di Milano. Documento di indirizzo per lo sviluppo del piano. Comune di Milano, Milano (2014).

9. PEAR Homepage, http://www.energialombardia.eu/, last accessed 2017/05/18.

10. Sharing Cities Homepage, http://sharingcities.eu/, last accessed 2019/04/24. 